Identification of Staphylococcus aureus that Isolated from Cosmetics Products and Detection resistant Genes by used Specialized molecular Markers

\title{
Identification of Staphylococcus aureus that Isolated from Cosmetics Products and Detection resistant Genes by used Specialized molecular Markers \\ Anfall Mohammed Juma(Msc) ${ }^{1}$, Talfan Anad Ahmed( $(\mathrm{PhD})^{2}$, Ammar Ahmed Sultan $(\mathrm{PhD})^{3}$ and Abbas Abod Farhan $(\mathrm{PhD})^{4}$
}

\begin{abstract}
Background:Cosmetics as well as (Make-up) are used to enhance the appearance or odor of the body and many cosmetics are designed to be placed on the face or hair. Cosmetics is an essential substance of growth and development of many types of micro-organisms because they contain nutrients facilitate the growth of these organisms.

Objective: Identification of Staphylococcus aureus by used 16srRNA gene and detection of virulence genes etb, mec A.

Patients and Methods: This study includes 100 samples of cosmetic products which are the Compact powder, Foundation, Lipstick and Mascara . Isolated Staphylococcus aureus , identification it and detection of resistant genes by used Polymerase Chain Reaction technique.

Results: 35 isolates were identified as Staphylococcus aureus . 4 isolates were identified genetical by 16srRNA gene and 3 isolates detection of resistant genes mecA, etb by used Polymerase Chain Reaction technique. The results of the genetic identification of the 16srRNA using (PCR), revealed that all S.aureus isolates which were 4 were positive and the results of resistant genes mec $\mathrm{A}$ and etb revealed that all S.aureus isolates which were 3 isolates were containing mec A gene depending on the appearance of band asize of(300 base pair) in the agarose gel and all S.aureus isolates were not containing etb gene .

Conclusion: It was observed that all S. aureus isolates were resistant for methicillin and that all S.aureus isolates have not Endothelin receptor Type B .
\end{abstract}

Key words: Cosmetic productes, Staphylococcus aureus ,Molecular detection, Resistant genes.

Corresponding Author: anfallmohammed@gmail.com

Received: $2^{\text {nd }}$ October 2017

Accepted: $14^{\text {th }}$ November 2017

https://doi.org/10.26505/DJM

${ }^{1,2,3,4}$ Biology Department- College of Education for Pure Sciences- Diyala University - Diyala-Iraq.

\section{Introduction}

Cosmetic products (Make-up) are used to enhance the appearance or odor of the body and many cosmetics are designed to be placed on the face or hair, in the 21 st century are spread widely and cosmetics are used by More women compared with men and cosmetics generally consists of a mixture of chemicals and some contain natural materials while others consist of synthetic materials [1] Cosmetics is an essential substance of growth and development of many types of microorganisms because they contain nutrients facilitate the growth of these organisms like water, fats, sugars, proteins, vitamins and 
alcohol [2] Most studies of micro-organisms in presence of cosmetics is the bacterium Pseudomonas aeruginosa and Klebsiella oxytoca and Pseudomonas cepacia and Staphylococcus aureus and Escherichia coli and Candida albicans and Enterobacter gergoviae [3] Staphylococcus aureus are Gram positive bacteria and be of spherical shape and present in the nose and respiratory tract, the skin and often positive catalase test and it goes artsy optional anaerobic and can grow without the need for oxygen [4] S. aureus causes a number of secondary infections of the skin such as dermatitis and Impetigo, boils and skin grain and also caused serious life-threatening diseases such as meningitis and inflammation of the bone marrow and endocarditis and pneumonia and blood poisoning, and more, these bacteria are from one of the most common of Hospital infection and often caused injuries inflammation after surgery [5].

\section{1-16srRNA gene}

Uses a 16srRNA gene and commodity prices and the primitive Prokaryotic species diagnosis routine (6), and uses the gene diagnosis of bacteria and rated and determine kinship relations between races and species, as well as the relationships between very old people (7). 16srRNA uses in diagnosis and classification of bacteria for several reasons:1-It is found in most types of bacteria.

2- It job be fixed and do not change with the passage of time and the evolution of living organisms.
3- Total length about 16srRNA gene [1500 bp]) and is long enough for the purpose of carrying genetic information [8].

\section{2- mec A gene}

mec A gene known A llmthisilin resistance gene, which encodes for a protein link to penicillin Low-affinity little protein binding affinities (PBP) 2a and this gene in strains Staphylococcus spp. 1lmthisilin resistance, is about A bp 21-60 mec gene from chromosome bar Staphylococcal mec (CSSmec) [9]. This gene is present in Staphylococcus aureus bacteria but it acquires from other external types is done by an as yet unidentified mechanism and have this gene resistant to B-lactam antibiotics [10].

\section{3- $e t b$ gene}

ETB is a Endothelin receptor Type B and it is a single copy in the passive genome and have a length of at least (36kb) and divide the region encoding to [7] axones separated by [6] antronat each length is over (' $23 \mathrm{~kb})$ [11]. Is gene etb sponsoring peeling skin syndrome (SSSS) Staphylococcal scalded skin peeling syndrome, also known as Ritter's disease that are the primary symptoms as crusting of the skin occurs in the outer skin layer and often the disease occurs in children [12].

\section{Patients and Methods}

Disinfecting hats toiletries cosmetics by ethanol $70 \%$ concentration before opening it and taking $1 \mathrm{~g}$ of each sample cosmetics and added to $9 \mathrm{ml}$ of Trypto Soy broth for (the powdered compact and lipstick and mascara) as for the Foundation has been taking $1 \mathrm{ml}$ of the sample and added to $9 \mathrm{ml}$ pepton water 
and conducted pepton per sample and then take $1 \mathrm{ml}$ of solution and placed in a sterile Petri dish and then plus $15 \mathrm{ml}$ Soy Trypton agar and incubated dishes temperature of 37 aerobically for 24 hours, and then the samples were planted on Mackonky agar for the purpose of differentiating between isolates. For positive and negative gram dye, but then they got tests and diagnostic tests and morphometric and biochemical for bacterial isolates [13]. Isolated and diagnosed bacterial isolates initially developing adopt agricultural qualities in terms of the size and color of the colonies, and the strength of the colonies as well as the ability to analyse red blood cells on blood agar Centre. Bacterial isolates were subjected to microscopic examination by taking a small tinge of colony and transferred to the glass slide and added gram dye to see bacteria interact with the dye and the form and manner of cells grouped [14]. The tests were conducted following biochemical to diagnose bacterial isolates the level type as indicated in [15].

\section{Bacterial DNA extraction}

Bacterial DNA was isolated using several extraction (Bacteria DNA Mini kit) fitted from Bionner company and follow the following steps:-

1- Transfer $1 \mathrm{ml}$ of bacterial isolates after 24 hours to Eppendrof $1.5 \mathrm{ml}$.

2- Eppendorf tubes discarded central pipe for $14000 \mathrm{rpm}$, floating neglected.

3- Added 200 microlater of GT buffer to Eppendrof tubes and mix it thoroughly .

4- Added 20 microlater of the enzyme Proteinase $\mathrm{K}$ record in accordance with paragraph (4-1-2-3) into the pipe and then merged mediated Vortex mixer well, then placed inside a water bath for ten minutes and the temperature $60^{\circ} \mathrm{c}$ and heart pipe three times every three minutes during the cuddling.

5- Added 200 microliter of GB buffer into the pipe and then merged with the mediation well Vortex mixer for 10 seconds and then placed inside a water bath Water bath for ten minutes and the temperature to $70^{\circ} \mathrm{c}$ and flipped the pipe three times every three minutes during the cuddling.

6- Added 200 microlitr of absolute ethanol Absolute cold to piping and then mix gently through the heart of the pipes to precipitate DNA.

7- The column is placed in the collection tube Column GD Collection tube $2 \mathrm{ml}$ and transfer all the batter.

8- Central pipe renounced for two minutes fast 14000 RPM then contents to new collection tube.

9- Added 400 microlitr of W1 buffer to GD column.

10- Mixture pipes quickly jettisons 14000 rpm for 30 seconds then put GD column in a tube.

11- Added 600 microlitr of Wash buffer to GD column.

12- Run the Central profiles for a minute 14000 RPM.

13- Give central profiles for three minutes fast $14000 \mathrm{rpm}$ for a minute to dry the column. 
Identification of Staphylococcus aureus that Isolated from Cosmetics Products and Detection resistant Genes by used Specialized molecular Markers

Anfal Mohammed Juma

14- Move the column GD to clean Eppendorf tube $1.5 \mathrm{ml}$.

15- Add 50 microliter of Elution buffer heater 70 degree $^{\circ} \mathrm{c}$ to pipes and pipe left for five minutes, then fired centrally for half minute $14000 \mathrm{rpm}$ speed so that DNA is obtained.

\section{Gel Electrophoresis}

Run the migration of DNA extracted according to (16) and as follows: Attended gel agaros $1 \%$ concentration of melt $(1 \mathrm{~g})$ of agaros $(100 \mathrm{ml})$ of saline solution $10 \times \mathrm{TBE}$ after diluted 10 times to get $1 \mathrm{x}$ TBE, hot the agaros to a boil and leave to cool down to Temperature $\left(45^{\circ} \mathrm{c}\right)$, then added to a final concentration of the ethidium bromide dye 0.5 micrograms $\mathrm{per} / \mathrm{ml}$ using the storage solution to record this dye then mix well the agaros to base plate set Tray briefed his dissatisfaction about duct tape and well, then comb proved to configure drill Wells designed to download samples and then pour agaros quietly and continuously to avoid air bubbles, then leave the gel solidifies at room temperature, and calmly comb for Duct tape. Then move the gel with the template to outdoor posting containing a suitable size covers jellies of TBE $1 \mathrm{x}$ then got carry Samples for posting ( 5 microlater) of DNA template and then mixing it with (3 microlater) $6 x$ download buffer using micropipette . After the migration process is made power supply voltage of $100 \mathrm{v} / \mathrm{cm}$ for (45 minutes) until the arrival of the samples before the end of the gel, after completing the migration process transferring the action to exposed to the source of the radiation exposure in violet. UV-Transilluminator when wavelength 320 nanometers.

\section{Polymerase Chain Reaction}

Gene was detected using PCR technique and follow the following steps:

1- Mix Master President attended the interaction mixture and add the following ingredients in a sterile tube as in table (1) mix the ingredients with a glass micro pipette minute by dragging it several times and then put in your profiles for 10 seconds.

2- Spread the mixture on the sterile tubes $0.5 \mathrm{ml}$ size 8 and mentor as samples to be examined and $15 \mu \mathrm{L}$ of the mixture for each tube.

3- Add $(5 \mu \mathrm{L})$ from a DNA template of each sample into the tube of his custom, the distributed Master Mix on the pipe before transfer of DNA to avoid contamination.

4- Use centrifuge for (15 seconds) to collect drips Seagrasses Central expulsion pipe wall and relegated to down for the tube keeping the final size of a mixture of interaction $20 \mu \mathrm{L}$.

Optimal conditions of mecA, 16srRNA, etb gene amplification: Replication steps were performed to investigate the level of S.aureus bacteria and detection mecA, 16srRNA, etb gene according $(17,18)$ PCR device is programmed, as shown in table (2).

\section{Results}

Tested four samples of S.aureus bacteria that carry sequences (1-10-12-14), having chosen these samples for genetic diagnosis by 16 srRNA gene and detection of virulence 
Identification of Staphylococcus aureus that Isolated from Cosmetics Products and Detection resistant Genes by used Specialized molecular Markers

genes and genes exist etb, mecA, using a technique (PCR) and rely on Primers specialized etb genes, MecA and fitted by a company (Korea/Bioneer) according to the sequence designed by $(17,18)$, table (3). have been programming device (PCR) as shown in the table (2) and the use of DNA template extracted by (Bacteria DNA Mini kit) is equipped by Bioneer Corporation, and has been detected Bacterial DNA extraction products using electric agaros gel, and use the optical density measurement device Spectrophotometer with purity of samples ranging from (2-1.8). nomads your output sequence polymerase 16srRNA gene on agaros gel focus (1\%) (1) voltage (Volt), noting the emergence of one package of all pits after exposing to UV gels as the picture (1). This demonstrates the link initiator with complementary sequence to tape the template when comparing packages with volumetric Ladder DNA evidence-doubled is equipped by a company (Korea/Bioneer), noted that the package sizes similar to expected size is (1400 pb), current study [4] S.aureus bacteria samples were have 16srRNA, as well as posting results showed a Electrical resistance genes etb, mecA said 3 isolates of S.aureus bacteria $(100 \%)$ The container was gene mesA and the size of the resulting beams (300bp) and is the headquarters for the volume of expected output [533bp], For gene etb results showed that all isolates were noncontainer on this gene.

Table (1): The main interaction Master Mix.

\begin{tabular}{|c||c||c||}
\hline Final Concentration & Volume For 1 Tube & Materials Concentration Manufacturer \\
\hline \hline$\ldots \ldots .$. & $6 \mu \mathrm{L}$ & D.W \\
\hline \hline $1 \mathrm{x}$ & $5 \mu \mathrm{L}$ & Accupower @ PCR Premix \\
\hline \hline $10 \mathrm{pmol}$ & $2 \mu \mathrm{L}$ & Primer - F ( 10 pmol ) \\
\hline \hline $10 \mathrm{pmol}$ & $2 \mu \mathrm{L}$ & Primer - R ( 10 pmol ) \\
\hline \hline$\mu \mathrm{L} 15$ & & Total reaction Volume \\
\hline
\end{tabular}

Table (2): program amplification of mecA, 16srRNA, etb gene by using P.C.R technology.

\begin{tabular}{|c|c|c|c|c|c|c|c|c|c|}
\hline \multirow{4}{*}{$\begin{array}{l}\text { Type of } \\
\text { primers }\end{array}$} & \multicolumn{9}{|c|}{ PCR Conditions Temperature / Minute } \\
\hline & \multicolumn{4}{|c|}{ Denaturation } & \multirow{2}{*}{\multicolumn{2}{|c|}{ Annealing }} & \multirow{2}{*}{\multicolumn{2}{|c|}{$\begin{array}{l}\text { DNA- } \\
\text { extension }\end{array}$}} & \multirow{3}{*}{$\begin{array}{l}\text { Expected } \\
\text { size of } \\
\text { products } \\
\text { (bp) }\end{array}$} \\
\hline & \multicolumn{2}{|c|}{ One cycle } & \multicolumn{2}{|c|}{40 cycles } & & & & & \\
\hline & & Min & ${ }^{\circ} \mathrm{C}$ & Min & ${ }^{\circ} \mathrm{C}$ & Min & ${ }^{\circ} \mathrm{C}$ & $\overline{\mathrm{Min}}$ & \\
\hline 16srRNA & 94 & $5 \mathrm{~min}$ & 94 & $1 \mathrm{~min}$ & 42 & $1 \mathrm{~min}$ & 72 & $5 \mathrm{~min}$ & 400 \\
\hline $\begin{array}{l}\text { mecA } \\
\text { etb }\end{array}$ & 94 & $3 \mathrm{~min}$ & 94 & $1 \mathrm{~min}$ & 60 & $\begin{array}{l}1.30 \\
\min \end{array}$ & 72 & $2 \min$ & $\begin{array}{l}533 \\
582\end{array}$ \\
\hline
\end{tabular}


Identification of Staphylococcus aureus that Isolated from Cosmetics Products and Detection resistant Genes by used Specialized molecular Markers

Anfal Mohammed Juma

Table (3): shows the variety and size of primers sequences expected output for each primer, according to $(17,18)$.

\begin{tabular}{|c|c|c|c|}
\hline $\begin{array}{l}\text { Product } \\
\text { size }\end{array}$ & bp & Primer sequence & Primer \\
\hline \multirow{2}{*}{1500} & 20 & 5"- AGA GTT TGA TCC TGG CTC AG-3" & 16srRNA 1 \\
\hline & 15 & 5"- CAA GGC ATC CAC CGT-3" & 16srRNA 2 \\
\hline \multirow{2}{*}{533} & 22 & 5"-AAA ATC GAT GGT AAA GGT TGG C-3" & mec-A 1 \\
\hline & 22 & 5"-AGT TCT GCA GTA CCG GAT TTG C-3" & mec-A 2 \\
\hline \multirow[b]{2}{*}{582} & 20 & 5"- ACA AGC AAA AGA ATA CAG CG-3" & etb 1 \\
\hline & 20 & 5"- GTT TTT GGC TGC TTC TCT TG-3" & etb 2 \\
\hline
\end{tabular}

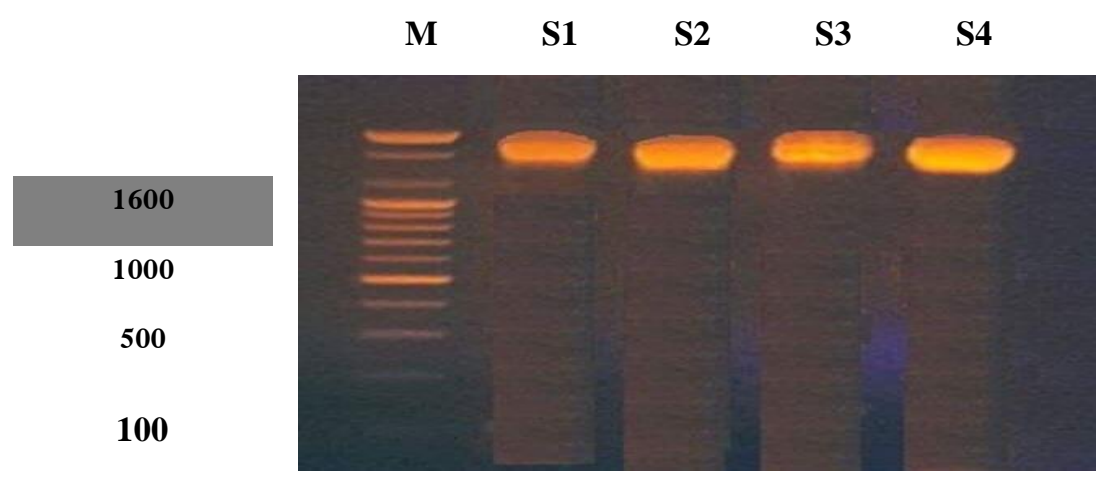

Figure(1): The Electrophoresis of 16srRNA gene on agarose gel using PCR for S.aureus , 1\%, 100 volts for one hour.

$(\mathrm{S} 1)=$ Sample $(1)$ of S.aureus , (S2)= (12) of $\quad(\mathrm{S} 4)=$ Sample (14) of Sample (10) of S.aureus , (S3)= Sample S.aureus , (M)= Marker 100-2000pb.

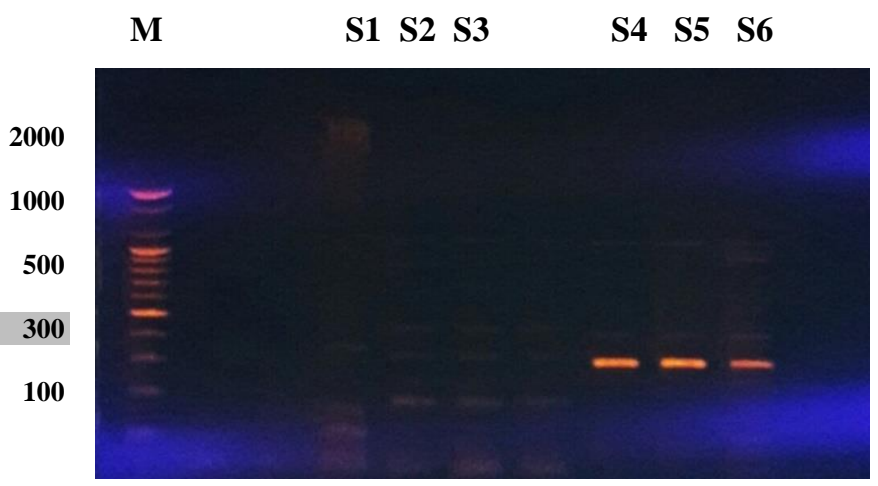

Figure (2): The Electrophoresis of etb, mecA gene on agarose gel using PCR for S.aureus , 1\%, 100 volts for one hour. 
$(\mathrm{S} 1)=$ Sample (1) of S.aureus for etb gene , (S2) = Sample (10) of S.aureus for etb gene, $(\mathrm{S} 3)=$ Sample (12) of S.aureus for etb gene , $(\mathrm{S} 4)=$ Sample (1) of S.aureus for mecA gene , (S5)= Sample (10) of S.aureus for mecA gene, $\quad(S 6)=$ Sample (21) of S.aureus for mecA gene, $(\mathrm{M})=$ Marker 100-2000pb.

\section{Discussion}

The result of 16srRNA compared with the results of the (18), gene 16srRNA, that Widely used to diagnose bacterial species and is used in classification and learn the the relationships between species and this gene is not homogeneous and identical in all living where there are a range of ambient Lunar occurring during the process of evolution (19), and when we compare the result of mesA gen with presenting her findings (17) in Iraq which was the source of his retirements of blood and urinary tract infections with all isolates container on gene mesA (100\%) and the resulting packet size matches the size of the expected output (533bp) due to differences in the type and source of isolates under study, and there was this result with the findings (20). For etb gen the result does not correspond with the findings (17) where all isolates from blood and cause urinary channel etb gene container $(100 \%)$ And different results due to differences in the source and type of samples.

\section{References}

[1]Günther Schneider, Sven Gohla, Jörg Schreiber, et al. "Skin Cosmetics" in Ullmann's Encyclopedia of Industrial
Chemistry , Wiley-VCH,Weinheim. 2005. doi:10.1002/14356007.a24_219.

[2] Herrera, G.A. Microbiological analysis of cosmetics. Methods Mol. Biol.,2004. 268, 293-295.

[3]SCCP.Scientific Committee on Consumer Products. The SCCP's Notes of Guidance for the Testing of Cosmetic Ingredients and Their Safety Evaluation. .(accessed on 11 November2015).Availableonlinehttp://ec.eur opa.eu/health/scientific_committees/consum er_safety/docs/sccs_s_006.pdf .

[4]Masalha M; et al. "Analysis of Transcription of the Staphylococcus Aureus Aerobic Class Ib and Anaerobic Class III Ribonucleotide Reductase Genes in Response to Oxygen". Journal of Bacteriology.2001. 183 (24): 7260-7272. [5]Bowersox, John.. "Experimental Staph Vaccine Broadly Protective in Animal Studies". NIH. (27 May 1999). Archived from the original on 5 May 2007. Retrieved28 July 2007.

[6] Jongsik C., Jae-Hak L., Yoonyoung J., Mungjin K., Seil K., Byung K., YoungWoon L. EzTaxon: aweb-based tool for the identification of prokaryotec based on $16 \mathrm{~S}$ ribosomal RNA gene Sequences. Seoul National University, Repuplic of Korea, International Journal of Systematic and Evolution Microbiology,2007. 57,22592261.

[7]Garrity, G. M., and J. G. Holt. The road map to the manual,2001. p.119-166. In G. M. Garrity (ed), Bergey's manual of 
Identification of Staphylococcus aureus that Isolated from Cosmetics Products and Detection resistant Genes by used Specialized molecular Markers Anfal Mohammed Juma

systematic bacteriology.Springer-Verlag, New York, N.Y.

[8]Patel, J. B. 16S rRNA gene sequencing for bacterial pathogen identificationin the clinical laboratory.2001. Mol. Diagn. 6:313321.

[9]Wielders C. L. C. , A. C. Fluit, S. Brisse, J. Verhoef, and F. J. Schmitz . mecA Gene Is Widely Disseminated in Staphylococcus aureus Population. JOURNAL OF CLINICAL MICROBIOLOGY, Nov. 2002, p. 3970-3975.

[10]Pattee, P. A. Staphylococcus aureus. Genet. Maps 2001. 5:22-27.

[11]Takeshi M., Yasuyoshi S., Makoto I., Futoshi I., Teizo I. Structure of the bovine ETB endothelin receptor gene. Biochem. J.1992. 287, 305-309 (Printed in Great Britain).

[12]M. Bukowski, Benedykt W., Crzegorz D.Exfoliative Toxins of Staphylococcus aureus . Jagiellonian University, Krakow, Poland, Toxins, 2010. 2,1148-1165.

[13]British pharmacopeia. London Appendix XVI B2A409-A416,2010. Microbial Examination of Non Sterile Products.

[14]Harley, J. P. And Prescott, L . M. Laboratory Exercises in Microbiology . 5 th.

Ed. The Mc Grow - Hill companies,2002, Inc. New York . 8 (13) : $456-459$.

[15] Forbes,B.A.; Sahm,D.F.and Weissfeld , A.S. Baily and scotts Dignostic Microbiology. 1lth edition . Mosby .2007, Inc . Baltimore, USA.,302-309.

[16] Sambrook , J. and Russell , D.W . Molecular Cloning : A Laboratory manual . 3rd edition . Cold spring Harbor ,2001, New York, 8(2) : 512-514.

[17]Hamza, L. F., A. H. Al-Marzoqi, Gh. M. Aziz, Z. M. Altaee. Molecular Study of Virulence Genes of Staphylococcus aureus from Various Clinical Origins by PCR. University of Babylon, Medical Journal of Babylon,2015, Vol.12, No.3:677-688.

[18] Mert S., A. F. Yenidunya and H. Gunes. Identification of staphylococci by $16 \mathrm{~S}$ internal transcribed spacer rRNA gene restriction fragment length polymorphism. Journal of Medical Microbiology (2005), 54, 823-826.

[19] Pfister, P., S. Hobbie, Q. Vicens, E. C. Bottger, and E. Westhof. Themolecular basis for A-site mutations conferring aminoglycoside resistance:relationship between ribosomal susceptibility and X-ray crystal structures.Chembiochem,2003, 4:1078-1088.

[20]Joa-Ann M., J. Z. D. champ, J. M.Conly , K. Zhang. Novel Multiplex PCR Assay for Detection of chlorhexidin Quaternary Amonium , Mupirocin, and Methicillin Resistance Genes with Simultaneous Discrimination of Staphylococcus aureus from coagulase Negative Staphylococci. University of Calgary, Alberta, Canada, American Society for Microbilogy Journal of Clinical Microbiology. 2016. 